\title{
Imperfect information and training quality
}

\author{
Citation for published version (APA):
}

Smits, W. (2003). Imperfect information and training quality. Researchcentrum voor Onderwijs en Arbeidsmarkt, Faculteit der Economische Wetenschappen. ROA Research Memoranda No. 1E https://doi.org/10.26481/umaror.200301E

Document status and date:

Published: 01/01/2003

DOI:

10.26481/umaror.200301E

Document Version:

Publisher's PDF, also known as Version of record

\section{Please check the document version of this publication:}

- A submitted manuscript is the version of the article upon submission and before peer-review. There can be important differences between the submitted version and the official published version of record.

People interested in the research are advised to contact the author for the final version of the publication, or visit the DOI to the publisher's website.

- The final author version and the galley proof are versions of the publication after peer review.

- The final published version features the final layout of the paper including the volume, issue and page numbers.

Link to publication

\footnotetext{
General rights rights.

- You may freely distribute the URL identifying the publication in the public portal. please follow below link for the End User Agreement:

www.umlib.nl/taverne-license

Take down policy

If you believe that this document breaches copyright please contact us at:

repository@maastrichtuniversity.nl

providing details and we will investigate your claim.
}

Copyright and moral rights for the publications made accessible in the public portal are retained by the authors and/or other copyright owners and it is a condition of accessing publications that users recognise and abide by the legal requirements associated with these

- Users may download and print one copy of any publication from the public portal for the purpose of private study or research.

- You may not further distribute the material or use it for any profit-making activity or commercial gain

If the publication is distributed under the terms of Article $25 \mathrm{fa}$ of the Dutch Copyright Act, indicated by the "Taverne" license above, 


\title{
Imperfect Information and Training Quality
}

\author{
ROA-RM-2003/1E \\ Wendy Smits*
}

* I would like to thank Lex Borghans, Giorgio Brunello, Monojit Chatterji, Arnaud Dupuy, Bart Golsteyn, Hans Heijke, Philip Marey, Christoph Meng and seminar participants of the 1997 EALE in Aarhus, the 1998 EALE in Blankenberge and Maastricht University, for many helpful comments on an earlier draft of this paper. Financial support from the Netherlands Organization for Scientific Research (NWO) is also gratefully acknowledged.

\section{Research Centre for Education and the Labour Market}

Faculty of Economics and Business Administration Maastricht University

Maastricht, March 2003 
ISBN 90-5321-358-9

Sec03.019.doc 


\begin{abstract}
This paper develops a theoretical model in which the level of training provided by a firm is not observed by workers. It is therefore not possible to have training wages completely contingent upon the level of training provided. Training wages will be too high. This, in turn, prevents firms from recouping the full benefits from training and leads to underinvestment. The more general the training is, the more severe this underinvestment problem.
\end{abstract}





\section{Introduction}

Apprenticeship training has received a great deal of attention over the past 10 years, both from economists and from policymakers. A common view is that an apprenticeship system is a better instrument for bridging the gap between education and the labour market than school-based education. The best known example is Germany, where an apprenticeship system seems to operate very successfully, resulting in a highly qualified labour force and relatively low youth unemployment (Lieshout, 1996). For this reason, the German apprenticeship system is taken as an example for several countries that are trying to improve their system of vocational education, notably the UK and the US (Steedman, 1993; OECD, 1994; Den Broeder, 1995; Harhoff and Kane, 1997; Smits and Stromback, 2001).

For an apprenticeship system to function well, however, there must firms willing to participate and offer a sufficient number of apprenticeship places. Unlike a school, which aims to transmit knowledge and skills, a firm's primary activity is to produce goods or services. Other activities, such as training workers, derive from this primary activity. Firms have different reasons for employing apprentices. The first reason for offering training is to provide for a future need for skilled labour (Stevens, 1994). Another reason for hiring apprentices may be their relatively low training wages, which enables firms to substitute apprentices for unskilled labour (Lindley, 1975).

The incentives for firms to train apprentices may impact on the quality of training places. Firms that train apprentices because of a future need for qualified workers have an interest in providing good quality training. Firms that have no long-term training interests are probably more interested in apprentices' current productivity than in their training (Ryan, 1994; Borghans and Smits, 1997).

Absence of a long-term training interest may result in apprentice exploitation if training quality is not perfectly observed by apprentices or not verifiable by a third party. Apprenticeship training usually comprises various components, such as courses at a training institute, training-on-the-job and learning-by-doing. Not all components are equally well observed by the apprentice. The quality of off-the-job training in training institutes is better observed than the 'learning-by-doing' component of the training. It will be difficult for an apprentice to judge whether certain tasks he has to fulfil are useful for his training or not. This is confirmed by research from Barron, Berger, and Black (1997a,b). A survey on training incidence and intensity among both firms and workers reveals that firms more often mention informal training such as 'informal co-worker training', workers mention more often training-off-the-job. Another finding is that firms report much more training 
than workers actually observe.

In this paper, I will develop a theoretical model in which the training quality or training level is not perfectly observed by the worker. The mechanism of the model is as follows. Training wages depend on the worker's observation of the training level. Since this observation is imperfect, a decrease in the training level will not be fully reflected in the training wages. The training firm can thus increase its profits by saving on training costs. As a result the training level will be below the social optimum. Both the firm and the worker would be better off if the training firm could commit to the socially optimal training level in turn for low training wages. However, as such a commitment is not credible, the worker will not be prepared to accept sufficiently low training wages. If the training is partly or entirely firm-specific, the firm will be able to share in the benefits from training (Becker, 1964) and will harm itself if it decreases the training level. Thus, the underinvestment problem will be more severe to the extent that the training is more general. I will show that for this reason it may be socially optimal to ensure that part of the apprenticeship training is firm-specific even in the presence of turnover.

Several authors have considered the issue of the training level as private information of the training firm. Both Chang and Wang (1996) and Katz and Ziderman (1990) have addressed informational asymmetries not between training firms and workers, as in this paper, but between the training firm and other firms. As an increase in the training level is not observed by other firms, it will not lead to an equivalent wage increase after the training period. Again, workers will not be prepared to share in the costs of general training but, opposed to my model, underinvestment will be less severe as firms can now appropriate some of the future returns to general training and will thus invest in general training, although in the case of labour turnover the investment will still be less than the social optimum.

My model is also related to the work of Schlicht (1996) and Malcomson, Maw, and McCormick (1997), who looked at informational asymmetries with respect to the training level between firms and workers. In Schlicht (1996), the training level is private information of the training firm and trainability of the worker is unknown ex ante. In my model, all workers are similar but firms differ in training efficiency, represented by differences in training cost functions. In some firms, it may be possible to embed training activities in the production process (training on-the-job and/or learning-by-doing), while in other firms most training has to be off-the-job. This explains the considerable differences in the level of apprenticeship training provided which appear to exist between firms in, for example, Germany (Lieshout, 1996). Not only between firms in different trades, but also between large and small firms 
and between traditional and technologically advanced firms (Damm-Rüger, Degen, and Grünewald, 1988). I will show that if there is perfect information on training quality, efficient training firms can provide general training and make profits, whereas in the case of imperfect information, the training level will be very low for all firms.

Malcomson, Maw, and McCormick (1997) considered the regulation of contract length to solve the underinvestment problem. If contract length exceeds the period needed to learn the trade, then the firm will have an interest in providing good quality training, since near the end of the contract the apprentice will be as productive as a skilled worker but still be receiving relatively low apprentice wages. In my model, I will consider a different solution. I will show that by making part of the training firm-specific, firms also profit from the training and as apprentices know that the firm now has less incentive to cheat, they will be prepared to accept low training wages.

The remainder of the paper is organized as follows. Section 2 introduces the model. In Section 3, the socially optimal level of training is derived and contrasted to private training outcomes under imperfect information. Next, Section 4 shows that the underinvestment problem can be mitigated by making part of the training firm-specific. Finally, Section 5 concludes the paper with some policy implications.

\section{A model for training}

I will consider a model for training in an economy with many unskilled workers and (training) firms. Firms live infinitely and workers live two periods. Workers can either undertake an apprenticeship during their first period or remain unskilled. Assuming constant returns to labour, I consider the training decision of a single firm and a single worker. Before the start of an apprenticeship, the worker and the firm negotiate about the worker's training wage. If they reach an agreement, the apprenticeship will start. If not, the worker will find unskilled employment in both periods.

At the beginning of the second period, the firm offers the worker a secondperiod wage. At that moment, both the training firm, the worker, and all other potential employers have complete knowledge of the worker's increase in human capital. If the worker accepts the wage offer, the employment relation continues. It is assumed that a fraction of the workers, denoted by $\gamma$, leaves for exogenous reasons. Other workers stay as long as the wage offer of the firm is not below their market wage. Assuming that the training firm possesses all bargaining power, the wage offer will equal the market wage. Since the returns to training in the training firm are always at least 
equal to the returns in any other firm, there is no risk of turnover due to wage differences in this model ${ }^{1}$. Furthermore, without loss of generality, it is assumed that there is no discounting between periods.

\subsection{Returns to training}

The training level, $h$, is expressed as the worker's increase in productivity. The potential productivity of the worker in the first period is given by:

$$
y_{1}=h^{0}
$$

where $h^{0}$ is the initial amount of human capital of the worker. This is the productivity that could be achieved without training. In the second period, the worker's productivity in his training firm becomes:

$$
y_{2}=h^{0}+h
$$

The human capital acquired is partly firm-specific. $\delta$ is a measure of the degree of firm-specificity of the training and is exogenous to the model $0 \leq$ $\delta \leq 1$. For $\delta=1$ the training is wholly firm-specific and for $\delta=0$ the training is wholly general. $\delta$ is known by both the firm and the worker.

The value of the training to other firms is $(1-\delta) h$. Since the post-training wage in the training firm, $W_{2}$, will be equal to the market wage, we have

$$
W_{2}=h^{0}+(1-\delta) h
$$

It follows that the returns to training for the firm are given by $\delta h$. The worker will capture the general part of the returns, while the firm will capture the specific part of the returns to the training.

\subsection{Training costs}

During the first period, the firm incurs training costs. Training costs include both lost productivity as a result of the training and the costs of supervision, materials, et cetera. Although firms all operate on the same market (produce the same goods), they may differ as to their organisational and production structure, which will be reflected in different training cost functions. Some firms may be more efficient in providing training than others, and hence

\footnotetext{
${ }^{1}$ Unlike in many other training models (e.g. Hashimoto (1981)), there is no random component involved in the returns of training inside or outside the training firm. In models with such a random component, there is a positive probability that the returns to training are higher outside the training firm, which leads to extra turnover.
} 
training costs at a given level of training may differ between firms. These differences in costs are explained entirely by differences between firms and are not the result of differences between workers. The cost of training for a firm $i$ as a function of the training level is given by $C_{i}(h) . C_{i}(h)$ is characterised by: $C_{i}^{\prime}(0)=0, C_{i}^{\prime}(h)>0$ if $h>0$ and $C_{i}^{\prime \prime}(h)>0$. This difference in cost functions between firms implies that the optimal level of training to provide differs between firms. Workers do not know the training cost function of a particular firm.

\subsection{Information structure}

Workers do not have full knowledge of the level of training provided during their apprenticeship. I have assumed that workers observe the level of training with an error. So, instead of the real training level, workers observe (see also Lang (1994)):

$$
h^{*}=h+u, E(u)=0, \operatorname{VAR}(u)=\sigma_{u}^{2}, 0 \leq \sigma_{u}^{2}<\infty
$$

This observation error has zero expectation and a variance $\sigma_{u}^{2}$. If $\sigma_{u}^{2} \rightarrow$ 0 , workers can observe the training level quite well, and for $\sigma_{u}^{2}=0$ their observation is perfect. If, on the other hand, $\sigma_{u}^{2} \rightarrow \infty$, the observation $h^{*}$ gives hardly any information on the real training level. Note that it is assumed that all workers observe the same training level, which means that the observation error, $u$, in a specific firm, is equal for all workers ${ }^{2}$. Firms do not know the observation error in advance, but they do know its variance.

Furthermore, workers know the distribution of the training output in the economy. Let $\bar{h}$ be the expected output from training. It then follows that:

$$
h=\bar{h}+e
$$

where $e$ is defined as the deviation from the expected level of training, which is $e=h-\bar{h}$. By definition $E(e)=0$. The variance in training output, given by $\sigma_{e}^{2}, 0<\sigma_{e}^{2}<\infty$, is known by both workers and firms.

Workers combine their observations of the training level in their firms with this additional information on the average output from training to obtain an optimal estimate of the training level. This optimal estimate for the level of training is given by:

$$
\widehat{h}=\lambda \bar{h}+(1-\lambda) h^{*}
$$

\footnotetext{
${ }^{2}$ If the observation error were not firm-specific, the training firm would search for the worker with the most favourable observation of the training level.
} 
The optimal weight, $\lambda$, depends on the variance of the two error terms. Minimising the mean square error of the estimate $\widehat{h}$ :

$$
E(\widehat{h}-h)^{2}=\lambda^{2} \sigma_{e}^{2}+(1-\lambda)^{2} \sigma_{u}^{2}
$$

gives $\lambda=\frac{\sigma_{u}^{2}}{\sigma_{u}^{2}+\sigma_{e}^{2}}$

The more accurate the observation by workers of the training level, the more weight will be given to this observation. If information is perfect, that is $\sigma_{u}^{2}=0$, the conjectured training level is equal to the real training level. If, on the other hand, the observation is very inaccurate, workers will place more weight on the average training level in the economy and less on their observation in the firm.

\subsection{Training wages and the participation constraint}

It is assumed that workers participate in the costs of training by accepting lower wages than their market wages in the absence of training. If the worker does not participate in the training programme, his wage will be equal to his initial productivity in both periods. A worker will therefore be willing to participate in the training programme as long as his life-time earnings will be at least equal to $2 h^{0}$.

If information is imperfect, however, a worker will not perfectly observe the level of training and will therefore not have full knowledge of his returns to training before the start of the second period. In that case, it is not possible to have training wages completely contingent on the level of training.

Workers will use their estimation on the training level to estimate their future market wage, which I have denoted by $\widehat{W}_{2}$. Substituting $\widehat{h}$ for $h$ in (3) gives $\widehat{W}_{2}=h^{0}+(1-\delta) \widehat{h}$. As long as the estimated life-time earnings in the case of apprenticeship training are at least equal to the earnings in the case of no training, workers will participate. The participation constraint for workers is thus given by:

$$
W_{1}+\widehat{W}_{2} \geq 2 h^{0}
$$

To determine the eventual training wage outcome, it is necessary to make some additional assumptions on the wage bargaining process at the start of the first period. It is assumed that at the time of bargaining the firm has already made the training investment. The firm therefore decides on the level of training before knowing the workers' estimation of the training level. As mentioned before, the observation error is equal for all workers. Since the firm has all bargaining power, the participation constraint (7) is binding and 
the eventual training wage will be given by $W_{1}=h^{0}-(1-\delta) \widehat{h}$. The eventual wages may be very unfavourable for the training firm, but since the firm has already made the training investment, it will not withdraw its training offer if workers accept the lowest wages that satisfy their participation constraint.

Note that if the training is completely firm-specific, workers do not share in the costs of training. The firm is willing to pay the full costs of firm-specific training because there is only exogenous turnover.

\section{$3 \quad$ Investment in training}

\subsection{Perfect information}

In the case of perfect information, workers know the level of training perfectly. This means that $h^{*}=h$ and $\sigma_{u}^{2}=0$. In that case, the training wage is completely contingent on the level of training and given by: $W_{1}=h^{0}-$ $(1-\delta) h$. Total profits of a firm $i$ are given by:

$$
\Pi_{i}=y_{1}-W_{1}-C_{i}(h)+(1-\gamma)\left(y_{2}-W_{2}\right)
$$

If a firm is very efficient in providing training, there may exist a training level, $h>0$, for which the first-period net productivity of workers $\left(y_{1}-C_{i}(h)\right)$, exceeds the first-period wage costs. In that case, the firm will offer training even if this training is completely general and as a consequence the future benefits of training to the firm are zero.

Substituting first-period and second-period productivity and wages in (8) gives:

$$
\Pi_{i}=(1-\gamma \delta)\left(h-C_{i}(h)\right)
$$

From (9) it follows that the profits of training for a firm are equal to the social profits of training. This is because, having all bargaining power, the training firm can appropriate the full returns from training by charging the worker a training fee equal to the returns from training. The optimal training level for the firm is found by maximising (9) with respect to the training level. The optimal training level is given by $h^{p}$ satisfying:

$$
C_{i}^{\prime}\left(h^{p}\right)=1
$$

Since $C_{i}^{\prime \prime}(h)>0$, it follows that $\Pi_{i}^{\prime \prime}(h)<0$, for all $h$, and therefore by assumption the second order condition holds.

If the market for training were competitive, that is, if firms had equal cost functions, total benefits would equal total costs. Then, the costs of training 
Figure 1: Training level under perfect information

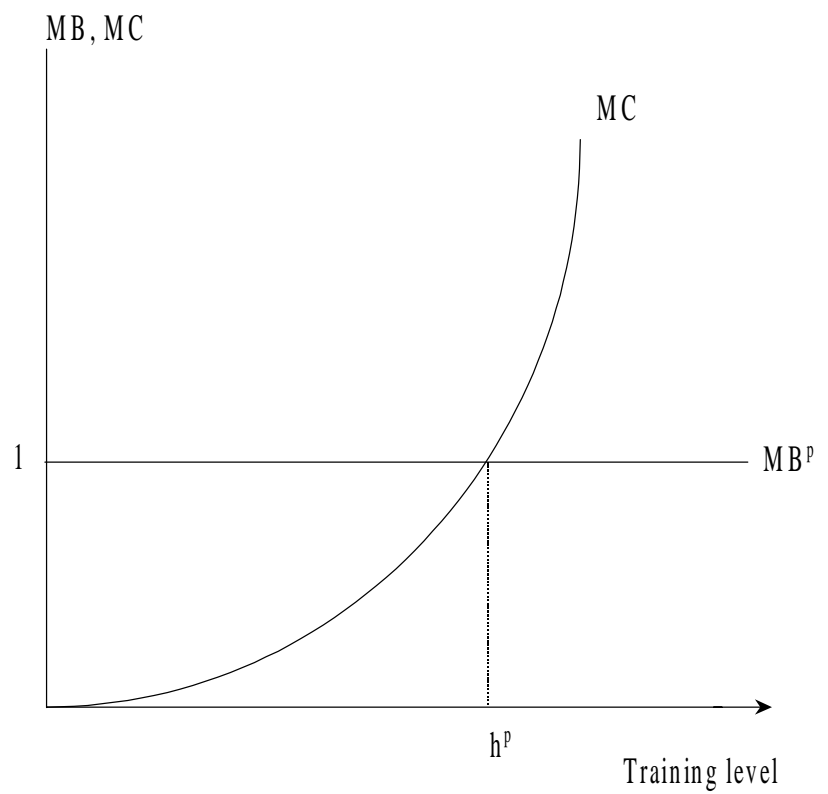

Note: The private optimal training level under perfect information $\left(h^{p}\right)$ is given by the intersection of the marginal benefits under perfect information $\left(\mathrm{MB}^{p}\right)$ and the marginal costs (MC).

would be shared according to the share in the benefits for both parties. So the training firm paid the firm-specific part and workers paid the general part of training, and both parties had zero profits. This is not true, however, if costs for a given training level differ between firms. Firms that have low training costs at a given level of training make more profits than firms that have high training costs. As mentioned above, firms can even make a profit if the training is completely general. Workers will not share in these profits as they have no bargaining power.

\subsection{Imperfect information}

Under perfect information, workers have perfect knowledge of their future returns to training and are therefore prepared to pay for their training by accepting lower wages during the training period than their market wages in 
the case of no training. If workers do not have full knowledge of the returns, however, an increase in the level of training will not be fully reflected in the expected training wages that the firm has to pay. Maximising profits with respect to training, the firm has to allow for the expected training wage it has to pay at a given amount of training, which is given by: $E W_{1}=$ $h^{0}-(1-\delta)(\lambda \bar{h}+(1-\lambda) h)$.

Expected profits for firm $i$ are then given by:

$$
E \Pi_{i}=(1-\delta) \lambda \bar{h}+(1-\lambda+\lambda \delta-\gamma \delta) h-C_{i}(h)
$$

The first order condition of the profit maximisation problem of the firm is now given by:

$$
C_{i}^{\prime}(h)=1-\lambda+\lambda \delta-\gamma \delta
$$

Since $0 \leq \delta \leq 1$ and $0 \leq \lambda \leq 1$, it follows that the optimal training level for the firm under imperfect information is less than the optimal training level under perfect information. This can also be seen from Figure 2. The optimal amount of training under perfect information $(\lambda=0)$ is given by $h^{p}$. Imperfect information decreases the expected marginal returns from training for all $h$. This is because an increase in the training level does not lead to an equivalent expected decrease of the training wages. An increase in the level of training of 1 increases general human capital of the worker by $1-\delta$ and as a consequence, wages need to fall by the same amount. Under imperfect information, however, the firm expects workers only to incorporate an increase in the training level of $1-\lambda$ in their estimation, and the expected wage decrease in the first period then equals $(1-\lambda)(1-\delta)$. Because the firm does not expect the worker to pay fully for his increase in general human capital, the marginal returns line shifts down. The optimal training level for the firm under imperfect information $(\lambda>0)$ is given by $h^{n p}$.

As $\lambda$ increases, the optimal training level for the firm decreases. Since workers only pay for an increase in their general human capital, the underinvestment problem will be more severe to the extent that the training is more general. If the training is completely firm-specific, $\delta=1$, profits depend solely on the real level of training, while if the training is completely general, the firm's profits depend solely on the conjectured training level. For $\delta=0$ and $\sigma_{u} \rightarrow \infty$ we have $h \rightarrow 0$ and $C_{i}^{\prime} \rightarrow 0$. So, imperfect information with respect to the training level will lead to less training than is socially optimal and the underinvestment problem becomes more serious as the training is more general ${ }^{3}$.

\footnotetext{
${ }^{3}$ Note that the assumption that the firm-specificity of the training is exogenous is of crucial importance for this conclusion. If firms could decide freely on the extent of firm-
} 
Note that if the variance in training levels between firms is low, for example because the training cost functions do not differ much, we also have $\lambda \rightarrow 1$. In that case, the average training level in the industry can be much lower than the social optimum, even if the variance of the observation error is low.

Figure 2: Training levels under perfect and imperfect information compared

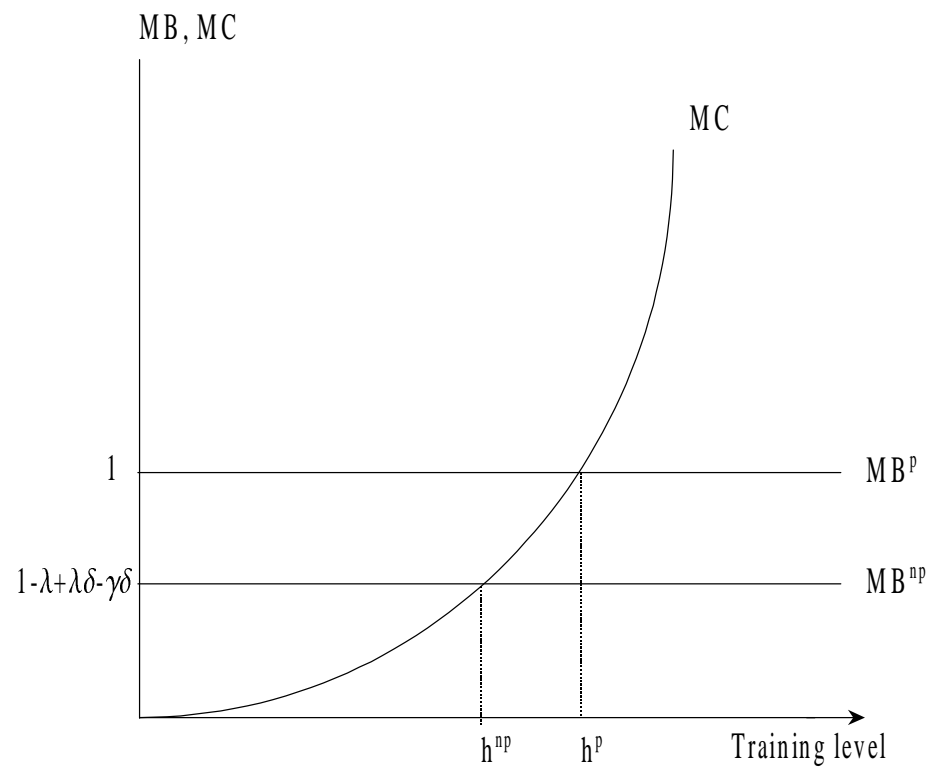

Note: The private optimal training levels under perfect and imperfect information ( $h^{p}$ and $h^{n p}$ ) are given by the intersections of the marginal benefits under perfect and imperfect information $\left(\mathrm{MB}^{p}\right.$ and $\left.\mathrm{MB}^{n p}\right)$ and the marginal costs $(\mathrm{MC})$, respectively.

The underinvestment problem cannot be solved by having the firm reveal the level of training. This is because the level of training that would be socially optimal is not credible to workers. The firm has an incentive to announce a higher level of training than it will actually provide.

specificity of the training, they would, in this setting, choose $\delta=1$ and no underinvestment would occur. 


\section{The optimal degree of firm-specificity of training}

The problem of underinvestment due to imperfect information is more severe when the training is more general. On the other hand, a higher degree of firm-specificity leads to a higher loss if the worker leaves after the training. The question is what degree of firm-specificity maximises social profits? Let $h(\delta)$ be the firm's optimal choice of the level of training as a function of the degree of firm-specificity following from (12). The social profits from training as a function of $\delta$ are then given by:

$$
\pi_{s}=(1-\delta \gamma) h(\delta)-C(h(\delta))
$$

which can be rewritten as the sum of the expected profits for the worker and the expected profits for the firm:

$$
\pi_{s}=(1-\delta) \lambda h(\delta)+(1-\lambda+\delta \lambda-\delta \gamma) h(\delta)-C(h(\delta))
$$

The first term on the left-hand side of equation (14) represents the part of the social profits that is appropriated by the worker. The training firm does not allow for this part when deciding on the training level. Maximisation of (14) with respect to $\delta$ gives the first order condition (provided that the restriction $0 \leq \delta \leq 1$ is not binding):

$$
(1-\delta) \lambda h^{\prime}(\delta)-\gamma h(\delta)=0
$$

The first term of equation (15) gives that part of a marginal increase in the level of training that is not paid for by the worker. A marginal increase in the degree of firm-specificity at a given training level will, however, lead to a larger loss when the worker leaves the training firm. This loss is given by the second term.

If $\lambda<\gamma$, the negative effect of the quit rate dominates the effect of incomplete information and $h^{\prime}(\delta)<0 \forall \delta$. In that case, it is never socially optimal for training to be partly firm-specific and the solution of the optimisation problem is given by $\delta=0$. If, on the other hand, $\lambda \geq \gamma$, it will be optimal for part of the training to be firm-specific. Lastly, if all workers stay in their training firms, that is if $\gamma=0$, the solution of the optimisation problem is given by $\delta=1$.

Figure 3 illustrates the optimisation problem. The figure presents the social profits as a function of $\lambda$ in the case that the training is completely general, completely firm-specific or chosen as the solution of equation (15). The cost function is chosen to be quadratic and the quit rate is set at 10 
percent. The figure shows that if the training is completely firm-specific, social profits do not depend on the degree of information incompleteness. If, on the other hand, the training is completely general, social profits decrease as information becomes more incomplete. This decrease can be partly offset by making the training partly firm-specific.

\section{Conclusions and policy implications}

This paper investigates the impact of informational asymmetries during the training period. Workers have incomplete information on the level of training in firms. It is therefore not possible to have training wages that are contingent on the amount of training provided. As a result, training wages are too low, which, in turn, prevents firms from recouping the full benefits from training and leads to underinvestment in training.

This finding has important consequences for government policies aimed at increasing the number of apprenticeships. If such policies mainly stimulate firms without a long-term training interest to hire apprentices, average training quality will fall. This will be the case with, for example, wage cost subsidies for firms that employ apprentices. Wage cost subsidies make it profitable to hire apprentices but give no incentive to provide these apprentices with good training. Therefore, there is a risk that most of the additional apprenticeship places generated by these subsidies are in firms are that provide low-quality training.

To prevent underinvestment in training, informational asymmetries should be removed. Or, in other words, the variance of the observation error, $\sigma_{u}^{2}$, must be reduced. This problem could be solved with a system of training certification, in which training standards are fixed and controlled by external bodies. If training in firms is regulated, workers are guaranteed a certain value of their training and will therefore be more prepared to accept low training wages. The case of Germany clearly supports this view. Apprenticeship training in Germany is regulated to a high degree and apprentices' wages are low (Casey, 1986; Steedman, 1993) resulting in a high level of training.

This is precisely the opposite of what Katz and Ziderman (1990) suggest. They argued that "certification may lead to less rather than more general training" because firms would then be less prepared to finance general training, since they risk losing their investment. The problem with this argument is, of course, that it is not firms but workers who should invest in general training. Under perfect information and in the absence of any other restrictions, such as credit constraints or minimum wages, there is no reason why 
Figure 3: Social profits from training and the optimal degree of firmspecificity $\left(\delta^{*}\right)$ as a function of the degree of information incompleteness $(\lambda)$
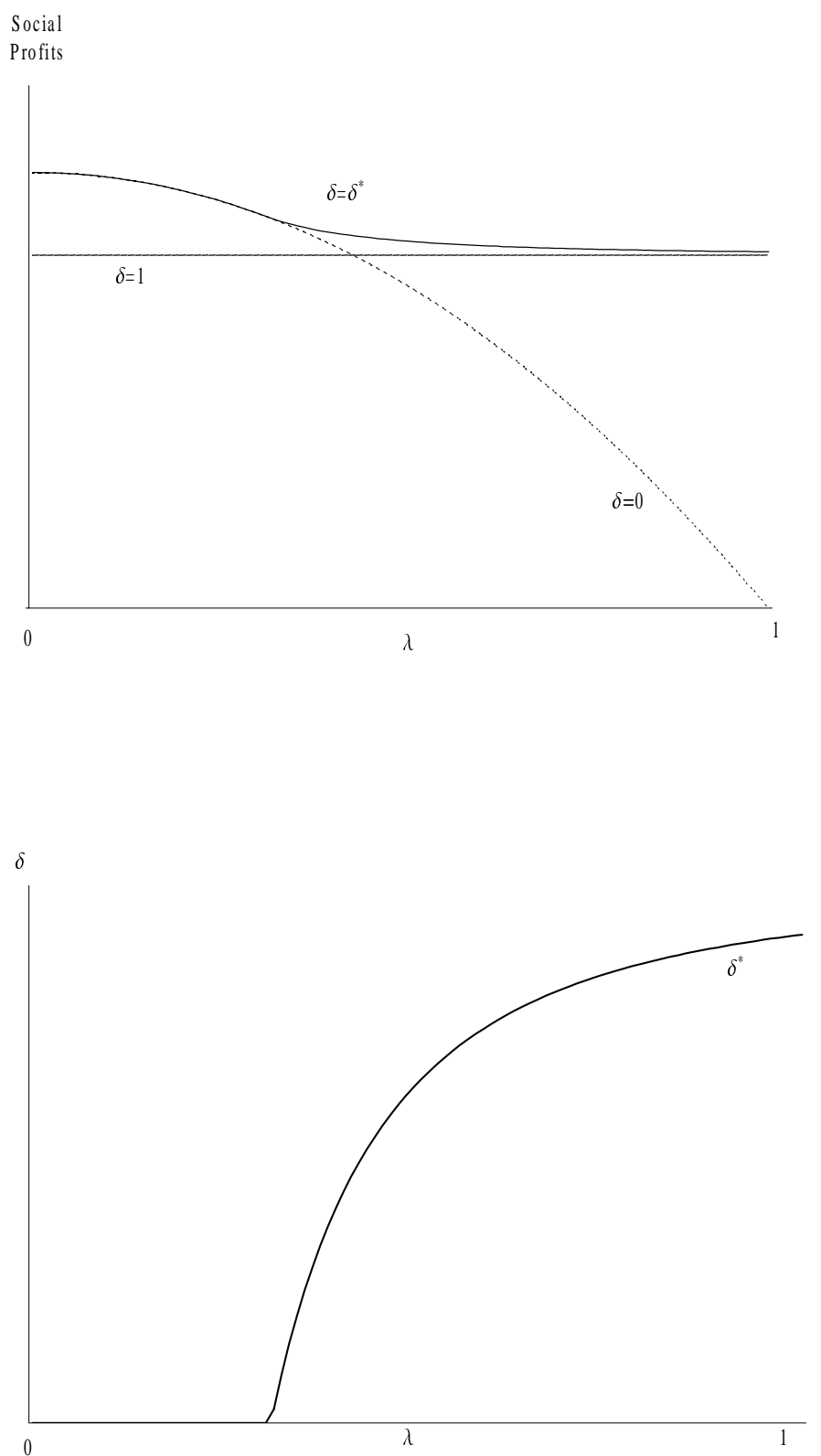

Note: Social profits are drawn for different degrees of firmspecificity of the training, namely completely firm-specific $(\delta=1)$, completely general $(\delta=0)$, and the optimal degree of firm-specificity $\left(\delta=\delta^{*}\right)$. $\delta^{*}$ is the degree of firm-specificity that maximises social profits at a given level of $\lambda$. 
firms should make the investment instead of workers. If credit constraints do prevent workers from investing in their human capital, other imperfections may indeed induce firms to invest. Still, it may be more efficient to remove these credit constraints and reduce informational asymmetries.

It is, however, probably not feasible to remove informational asymmetries completely. Even if training standards were fixed, external bodies would have problems in controlling these standards. For example, if certain standards were not reached, it would not always be clear whether this was due to the firm not providing enough training or the apprentice not putting in enough effort or not being able enough. Therefore firms should be given enough freedom to adapt part of their training to their own specific needs and circumstances. That is, training standards should not aim at training that is completely general. If part of the training is firm-specific, firms will have an incentive to provide good quality training.

\section{References}

Barron, J., M. Berger, and D. Black (1997a): On the Job Training. W.E. Upjohn Institute for Employment Research, Michigan.

Barron, J. M., M. C. Berger, and D. A. Black (1997b): "How Well Do We Measure Training?," Journal of Labor Economics, 15(3), 505-528.

Becker, G. (1964): Human Capital, A Theoretical and Empirical Analysis with Special Reference to Education. The University of Chicago Press, Chicago.

Borghans, L., And W. Smits (1997): "Succesfactoren in Het Leerlingwezen," Tijdschrift voor arbeidsvraagstukken, 13(4), 321-33.

Casey, B. (1986): "The Dual Apprenticeship System and the Recruitment and Retention of Young Persons in West Germany," British Journal of Industrial Relations, 24(1), 63-81.

Chang, C., And Y. Wang (1996): "Human Capital Investments under Asymmetric Information: The Pigovian Conjecture Revisited," Journal of Labour Economics, 14(3), 505-19.

Damm-Rüger, S., U. Degen, And U. Grünewald (1988): Zur Struktur der Betrieblichen Ausbildungsgestaltung. Ergebnisse Einer Schriftliche Befragung in Ausbildingsbetrieben Von Industrie und Handwerk. Bericht zur Beruflichen Bildung Heft 101, Berlin und Bonn. 
Den Broeder, C. (1995): "The Match Between Education and Work: What Can We Learn from the German Apprenticeship System?," Research Memorandum 118, Central Planbureau, Den Haag.

HarhofF, D., And T. J. Kane (1997): "Is the German Apprenticeship System a Panacea for the U.S. Labor Market?," Journal of Population Economics, 10(2), 171-96.

Hashimoto, M. (1981): "Firm-Specific Human Capital as a Shared Investment," American Economic Review, 71(3), 475-82.

Katz, E., AND A. Ziderman (1990): "Investment in General Training: The Role of Information and Labour Mobility'," Economic Journal, 100(403), 1147-58.

LANG, K. (1994): "Does the Human Capital/Educational Sorting Debate Matter for Development Policy?," American Economic Review, 84(1), 3538.

Lieshout, H. V. (1996): Beroepsonderwijs in Duitsland. Max Goote Kenniscentrum voor beroepsonderwijs en volwasseneneducatie, Amsterdam.

Lindley, R. M. (1975): "The Demand for Apprentice Recruits by the Engineering Industry, 1951-71," Scottish Journal of Political Economy, 22(1), $1-24$.

Malcomson, J., J. Maw, and B. McCormick (1997): "General Training by Firms, Contract Enforceability and Public Policy," Discussion Paper 21, University of Southampton.

OECD (1994): Apprenticeship: Which Way Forward? OECD, Paris.

Ryan, P. (1994): "Training Quality and Trainee Exploitation," in Britain's Training Decifit: The Centre for Economic Performance Report, ed. by R. Layard, K. Mayhew, and G. Owen, pp. 92-124, Aldershot. Avebury.

Schlicht, E. (1996): "Endogenous on-the-Job Training with Moral Hazard," Labour Economics, 3, 81-91.

Smits, W., And T. Stromback (2001): The Economics of the Apprenticeship System. Edward Elgar, Cheltenham.

Steedman, H. (1993): "The Economics of Youth Training in Germany," Economic Journal, 103, 1279-91. 
Stevens, M. (1994): "A Theoretical Model of on-the-Job Training with Imperfect Competition," Oxford Economic Papers, 46(4), 537-62. 